\title{
Farklı Buğday Genotiplerinde Kalite Parametrelerinin İncelenmesi Üzerine Bir Araştırma
}

\section{ismail SEVIM ${ }^{* 1}$ (D), Osman EREKUL ${ }^{2}$ (i)}

\author{
${ }^{1}$ Ege Tarımsal Araştırma Enstitüsü Menemen, Izmir \\ ${ }^{2}$ Aydın Adnan Menderes Üniversitesi Ziraat Fakültesi Tarla Bitkileri Bölümü, Aydın
}

Öz: Bu araştırma, bazı ekmeklik buğday çeşit ve hatları ile yerel çeşitlerin kalite parametrelerinin belirlenmesi amacıyla yürütülmüştür. Çalışmada 17 ileri kademe ekmeklik buğday hattı, 8 adet yazlık karakterli tescilli çeşit ve 5 adet yerel çeşit materyal olarak kullanılmıştır. Çalışmada yer alan genotiplere ait Protein Oranı (\%), Zeleny SDS (ml) ve Farinograf değerleri incelenmiştir. Yapılan çalışma ile genotiplerin ayrıntılı kalite potansiyelleri ortaya konularak karşılaştırılması amaçlanmıştır. Elde edilen sonuçlar özetlendiğinde, protein oranları \%9.1-14.6, Zeleny sedimantasyon değerleri 14-50 ml, arasında değişim göstermiştir. Ayrıca genotiplerin farinograf analizi ile hamur yoğurma özellikleri belirlenmiştir. Farinograf cihazı ile yapılan ölçümlerin bir sonucu olan Farinograf Kalite Numarası (FQN) 22 mm ile $>200$ mm arasında değer göstermiştir.

\section{Anahtar Kelimeler: Protein, Zeleny SDS, Farinograf}

\section{An Investıgatıon on Determınatıon of Qualıty Parameters of Dıverse Wheat Genotypes}

Abstract: This study was conducted in order to determine the quality parameters of some bread wheat varieties, lines and landraces. 17 advenced bread wheat lines, 8 registered spring varieties and 5 landraces were used as material. Moisture of genotype, protein content, Zeleny SDS and farinograph values were examined. The study aimed to compare the genotypes with detailed quality potentials.

When the result were summarized, protein content, Zeleny SDS of genotypes ranged between ,9.1-14.6\%, 14-50 ml, respectively. Inaddition, the reological properties of the dough were determined by farinograph and analyses. The Farinograph Quality Number (FQN), which is a result of measurements with the Farinograph device, ranged from $22 \mathrm{~mm}$ to $200 \mathrm{~mm}$.

Keywords: Protein, Zeleny SDS, Farinograph

\section{GiRiş}

İnsanoğlunun ilk kültüre aldığı tür olan buğday, dünyada en fazla üretimi yapılan ürünler arasında yer almaktadır. Tahılların bu kadar çok yetiştirilmesinin en önemli sebeplerinden bazıları; adaptasyon yeteneğinin yüksek olması, insan beslenmesinde temel gıda maddesi olarak kullanılması, kültüre alınan ilk bitki olması, yetiştiriciliği, taşıma, depolama ve muhafazasının kolay olması ve hayvan beslenmesinde de rahatlıkla kullanılabilmesidir.

Buğday'da ıslah çalışmaları Türkiye'de 1925 yılında başlamıştır. 1931 yılında yerel popülasyondan seleksiyon ile Ak-702 isimli buğday ilk olarak tescil ettirilmiştir. İlerleyen yıllarda hem yerel popülasyonlardan seleksiyon, hem de melezleme ıslahı ile geliştirilen çeşitler izlemiştir. Türkiye'de Ak-702 çeşidinden günümüze kadar geçen sürede 100'ün üzerinde buğday çeşidi tescil ettirilmiştir (Braun ve ark., 2001). 2020 yılı itibari ile tescil ettirilen ekmeklik ve makarnalık buğday çeşit sayıları 384 olarak göze çarpmaktadır (Anonim, 2020).

Üretici için buğdayda verimin arttırılması önemli olsa da, son yıllarda tüketiciye kaliteli ürün sunulması ve ürünün işleme aşamalarında kalite öne çıkan önemli bir husus olmuştur. Bu sebeple ülkemizde yeterli buğday üretimi olmasına rağmen verim öncelikli çok fazla çeşidin üretime girmesi, kaliteli çeşitlerin çiftçiye ulaştırılamaması, hastalık ve zararlı mücadelesinin yeterli düzeyde yapılamaması "Buğdayda Kalite" sorununun ortaya çıkmasına neden olmaktadır (Menderis, 2006).
Son zamanlarda organik ürünlere karşı artan ilgi ile fonksiyonel gıda arayışları, beslenme fizyolojisi açısından önemli vitamin, mineral ve lifli yapısının zenginliği ile öne çıkan eski buğdayları tekrar keşfetmeyi ve besin zincirine dahil etme eğilimini arttırmıştır.

Günlük yaşantımızda hareketsizlik ile beraber besinsel lif içeriği düşük gıdaların tüketimi neticesinde obozite, diyabeti, kalp/damar hastalıkları ve bağırsak hastalıkları gibi ciddi sağlık sorunlarında artış gözlenmektedir. Yüksek aminoasit içeriği, yüksek protein ve düşük alerjik özellikler yerel buğdaylara karşı olan ilgiyi arttırmaktadır. Tahıllarda bulunan antioksidanlar ve besinsel lif zenginliği, kronik hastalıkların oluşumunun önüne geçme açısından önemli bir potansiyele sahiptir (Mpofu ve ark., 2006; Serpen ve ark., 2008; Yiğit, 2019).

Türkiye'de modern buğday ıslah çeşitlerinin yanında geleneksel yöntemlerle yetiştirilen yerel çeşitlerin yetiştiriciliği yüzlerce yıldır yapılmaktadır. İkinci dünya savaşı sonuna kadar ülkemiz buğday tarımında buğday köy çeşitleri büyük ölçüde yer almaktadır (Kün, 1996). Bu çeşitlerin yetiştiriciliği geçmişle karşılaştırıldığında sürekli

*Sorumlu Yazar: ismail.sevim@tarimorman.gov.tr. Bu çalışma yüksek lisans tez ürünüdür ve Aydın Adnan Menderes Üniversitesi Bilimsel Araştırma Projeleri Komisyonu (Proje No: ZRF-19002) tarafından desteklenmiştir.

Geliş Tarihi: 23 Mayıs 2020

Kabul Tarihi: 15 Aralık 2020 
azalmaktadır. Nitekim 2009-2014 yıllarını kapsayan uluslararası bir araştırma sonucuna göre; ülkemizde 61 ilden toplam 1600 çiftçi tarlasından başak örneği toplanmış, sınıflandırma yapılmış ve bu sınıflandırma sonucu 3 buğday türü ve 6 alt türüne ait 95 farklı morfo-tip (botanik varyete) belirlenmiştir. Bu çalışma sonucuna göre, Mirza Gökgöl tarafından ülke genelinde yapılan çalışma ile karşılaştırıldığında; buğdayda genetik çeşitliliğin \%50 ile \%70 oranında kaybolduğu görülmektedir (Morgounov ve ark., 2016; Kan ve ark., 2015).

Unun kalitesini belirlemede birçok yöntem vardır. Bu yöntemlerden bir tanesi unun reolojik özellikleri hakkında bilgi veren farinograf cihazıdır.

Ekmeklik unlarda su absorbsiyonunun yüksek olması istenirken, yoğurma süresinin ise çok uzun olmaması istenmektedir. Yoğurma süresinin uzun oluşu ekmek yapımı aşamasında enerji ve zaman kaybına sebep olacağı için istenmeyen bir özelliktir. Farinogramın 500 konsistens çizgisini ortalaması için verilmesi gereken su miktarı, o un örneğinin su kaldırma miktarı olarak belirtilmektedir (Ünal ve Boyacıoğlu, 1984).

Ekmeklik buğdaylarda glüten miktarı ile kalitesinin belirlenmesi için sedimantasyon değerine bakılır. Yüksek sedimantasyon değeri bize özün (gluten) iyi su tuttuğunu ve ekmeğin iyi kabararak yüksek hacimli olacağını gösterir (Elgün ve ark., 2001).

Bu çalışma ile 2018 yılı hasat sezonunda elde edilen CIMMYT Meksika orijinli 17 ileri kademe ekmeklik buğday hattı, 8 adet yazlık karakterli tescilli çeşit ve 5 adet yerel çeşit kalite yönünden karşılaştırılmıştır. Araştırmada genotiplerin hamur özelliklerini belirlemek amacıyla farinograf ölçümleri yapılmış, protein miktarları ile Zeleny sedimantasyon değerleri karşılaştırılmıştır.

\section{MATERYAL VE YÖNTEM}

Çalışmada; 2017-18 üretim sezonunda yetiştirilen genotiplerden elde edilen tohumlar kullanılmıştır.

Ege Tarımsal Araştırma Enstitüsü Menemen deneme alanında yürütülmüş CIMMYT Meksika orijinli denemelerinden seçilen 17 hattan alınan örnekler,

Yazlık dilimde ekilen 8 adet tescilli çeşitten hasat sonrası yığından alınan örnekler,

Siyez yerel çeşidinin üretim sonrası hasadından alınan örnek,

Manisa yöresinde yetiştirilen 4 yerel çeşitten hasat sonrası yığınlardan alınan örnekler çalışma da kullanılmıştır.

Çizelge 1'de genotiplerin yetiştirilme yerleri belirtilmiştir.

Protein miktarı; Dumas yöntemine, azot tayin cihazı LECO FP 528 cihazı ile (azot oranı * 5.70) AOAC 992.23 metoduna göre belirlenmiştir (Anonymous, 2009).

Zeleny sedimantasyon; ICC Standart No: 116-1'e (Anonymous, 2008) göre yapılmıştır.
Farinograf analizi Brabender AT model 50 gram karıştırma ünitesine sahip cihaz ile AACC 54-21 (Anonymous, 1990) metoduna göre yapılmıştır. Farinograf analizi ile yapılan incelemeler;

- Farinograf Gelişme (yoğurma) Süresi (dk)(FGS) : Hamurun yoğrulmaya başlaması ile direnç 500 konsistens derecesine yükselmesine kadar geçen süredir.

- Farinograf Su Absorbsiyon Kapasitesi (\%)(FSAB) : Hamurun yoğrulması için gereken su miktarıdır.

- Farinograf Stabilitesi (dk)(FS) : Hamurun 500 konsistens çizgisini ortalamasından yumuşamaya kadar geçen süreye stabilite süresi ( $\mathrm{dk}$ ) denir.

- Farinograf 10. Dakika Yumuşama Değeri (BU)(FYUM10) : Kurvenin ortası ile 500 konsistens çizgisi arasında düşüş miktarına yumuşama derecesi denir ve konsistens derecesi cinsinden ifade edilir.

- Farinograf 12. Dakika Yumuşama Değeri (BU)(FYUM12) : Kurvenin tepe noktasından 12 dakika sonra, kurve ortasının 500 konsistens çizgisine olan uzaklığına yumuşama derecesi denir ve konsistens derecesi cinsinden ifade edilir.

- Farinograf Kalite Numarası (mm)(FQN)

Elde edilen bulgular istatistiki olarak değerlendirilmişti (Yurtsever, 1984).

\section{BULGULAR VE TARTIŞMA}

\section{Protein Oranı (\%)}

Protein oranı unun ekmeklik değerinin belirlenmesinde kullanılan, ekmeğin pişirme kalitesi ve hacminin oluşumunda önemli bir kalite kriteri olarak kabul görmektedir (Kihlberg ve ark., 2004; Mader ve ark., 2007). Kaliteyi önemli ölçüde etkileyen tane protein miktarı ve protein fraksiyonlarının dağılımı genotipten ve çeşitli çevre dış faktörlerinden kaynaklanan özelliklerine göre değişim göstermektedir (Erekul ve ark., 2005).

$\mathrm{Bu}$ çalışmada genotiplerin protein ortalaması \%12.1 bulunmuştur (Çizelge 2). En yüksek protein değeri \%14.6 ile yerel çeşitlerden olan Gıcık buğday da görülürken, \%9.1 değeriyle özel sektör çeşidi en düşük protein değerine sahip çeşit olarak karşımıza çıkmaktadır. Önceki çalışmalar da Triticum monococcum L. (Einkorn) buğdaylarının protein içeriklerinin ekmeklik buğdayla karşılaştırıldığında onlardan fazla olduğu tesbit edilmiştir (Borghi ve ark.,1996; Corbellini ve ark., 1999).

Çalışmadaki buğdayların çeşit, yerel çeşit ve hat bazında ortalama değerlerine bakacak olursak çeşitlerin \%11.7, yerel çeşitlerin \%12.3 ve hatların \%12.2 protein değeri aldığını görmekteyiz. Akçura (2001) Türkiye'nin değişik yerlerinden toplanan yerel ekmeklik buğday genotiplerinde protein oranını \%13.8-16.7, ıslah edilmiş çeşitlerde ise 


\begin{tabular}{|c|c|c|c|}
\hline No & Genotip & Pedigri & Temin yeri \\
\hline 1 & Meltem & Çeşit & Ege Tarımsal Araştırma Enstitüsü - Menemen \\
\hline 2 & Efe & Çeşit & Ege Tarımsal Araştırma Enstitüsü - Menemen \\
\hline 3 & Kayra & Çeşit & Ege Tarımsal Araştırma Enstitüsü - Menemen \\
\hline 4 & Cumhuriyet 75 & Çeşit & Ege Tarımsal Araştırma Enstitüsü - Menemen \\
\hline 5 & Ziyabey 98 & Çeşit & Ege Tarımsal Araştırma Enstitüsü - Menemen \\
\hline 6 & Nusrat & Çeşit & Ege Tarımsal Araştırma Enstitüsü - Menemen \\
\hline 7 & Ceyhan 99 & Çeşit & Ege Tarımsal Araştırma Enstitüsü - Menemen \\
\hline 8 & Özel Sektör Çeşidi & Çeşit & Ege Üniversitesi Çiftliği - Menemen \\
\hline 9 & Siyez & Yerel çeşit & Ege Tarımsal Araştırma Enstitüsü - Menemen \\
\hline 10 & Gıcık Buğday & Yerel çeşit & Gökçeören Köyü / Kula / Manisa \\
\hline 11 & Evren & Yerel çeşit & Güneşli Köyü / Gördes / Manisa \\
\hline 12 & Çalıbasan & Yerel çeşit & Güneşli Köyü / Gördes / Manisa \\
\hline 13 & Akbuğday & Yerel çeşit & Doğankaya Köyü / Akhisar / Manisa \\
\hline 14 & Hat 1 & 23.sawyt-306 & Ege Tarımsal Araştırma Enstitüsü - Menemen \\
\hline 15 & Hat 2 & 23.sawyt-308 & Ege Tarımsal Araştırma Enstitüsü - Menemen \\
\hline 16 & Hat 3 & 23.sawyt-314 & Ege Tarımsal Araştırma Enstitüsü - Menemen \\
\hline 17 & Hat 4 & 23.sawyt-316 & Ege Tarımsal Araştırma Enstitüsü - Menemen \\
\hline 18 & Hat 5 & 23.sawyt-321 & Ege Tarımsal Araştırma Enstitüsü - Menemen \\
\hline 19 & Hat 6 & 23.sawyt-327 & Ege Tarımsal Araştırma Enstitüsü - Menemen \\
\hline 20 & Hat 7 & 23.sawyt-332 & Ege Tarımsal Araştırma Enstitüsü - Menemen \\
\hline 21 & Hat 8 & 23.sawyt-339 & Ege Tarımsal Araştırma Enstitüsü - Menemen \\
\hline 22 & Hat 9 & 23.sawyt-344 & Ege Tarımsal Araştırma Enstitüsü - Menemen \\
\hline 23 & Hat 10 & 23.sawyt-347 & Ege Tarımsal Araştırma Enstitüsü - Menemen \\
\hline 24 & Hat 11 & 36.eswyt-106 & Ege Tarımsal Araştırma Enstitüsü - Menemen \\
\hline 25 & Hat 12 & 36.eswyt-115 & Ege Tarımsal Araştırma Enstitüsü - Menemen \\
\hline 26 & Hat 13 & 36.eswyt-122 & Ege Tarımsal Araştırma Enstitüsü - Menemen \\
\hline 27 & Hat 14 & 36.eswyt-123 & Ege Tarımsal Araştırma Enstitüsü - Menemen \\
\hline 28 & Hat 15 & 36.eswyt-136 & Ege Tarımsal Araştırma Enstitüsü - Menemen \\
\hline 29 & Hat 16 & 36.eswyt-144 & Ege Tarımsal Araştırma Enstitüsü - Menemen \\
\hline 30 & Hat 17 & 36.eswyt-145 & Ege Tarımsal Araştırma Enstitüsü - Menemen \\
\hline
\end{tabular}

\%13.9- 15.2 oranını bulduğunu ve bizim değerlerin üzerinde olduğu gözlenmiştir.

Tahıllar protein içeriklerine göre değerlendirildiğinde \%9.0 ve altı çok düşük olarak sınıflandırılmış, \%11.6-13.5 arası orta sınıf olarak kabul edilmiş, \%13.5- 15.5 arası ise protein oranları açısından yüksek sınıf olarak kabul edilmiştir (Williams ve ark., 1986a). Williams ve ark. 1986a'ya göre bu çalışmada yer alan genotipler orta protein değerine sahip olmuştur.

\section{Zeleny Sedimantasyon ( $\mathrm{ml}$ )}

Zeleny sedimantasyon testi buğday da gluten kalitesini belirlemek için yararlanılan bir analizdir (Özkaya ve Kahveci, 1989). Yüksek sedimantasyon değeri gluten proteinlerinin yüksek su tutma kapasitelerine sahip olduğu dolayısıyla da üretilen ekmeklerin yüksek hacimli olabileceğinin işareti

olarak değerlendirilmektedir (Elgün ve ark., 2001; Bulut, 2012).

Çizelge 3 incelendiğinde yerel çeşitlerin, çeşit ve hatlara göre oldukça düşük Zeleny sedimantasyon değerine sahip oldukları göze çarpmaktadır. Hatların Zeleny sedimantasyon ortalama değerleri $38 \mathrm{ml}$, en yüksek değer $50 \mathrm{ml}$ ile 22 numaralı hat verirken en düşük değer $31 \mathrm{ml}$ ile 27 numaralı hat vermiştir. Yerel çeşitler 14-25 ml arasında değişim gösterirken en düşük değeri Siyez almıştır. Çeşitler incelendiğinde Kayra ve Ceyhan 9945 ml ile en yüksek çeşit, özel sektör çeşidi ise $24 \mathrm{ml}$ ile en düşük çeşit olarak görülmektedir.

Yapılan farklı çalışmalarda sedimantasyon değerlerinin 30.5$61.0 \mathrm{ml}$ (Tayyar ve ark., 2005), 19.5-62.5 ml (Aydoğan ve 
Çizelge 2. Genotiplerin protein oranları (\%)

\begin{tabular}{|c|c|c|c|c|c|}
\hline No & Genotip & Protein(\%) & No & Genotip & Protein(\%) \\
\hline 1 & Meltem & 13.3 & 16 & 23.sawyt-314 & 12.8 \\
\hline 2 & Efe & 13.7 & 17 & 23.sawyt-316 & 11.7 \\
\hline 3 & Kayra & 11.5 & 18 & 23.sawyt-321 & 12.2 \\
\hline 4 & Cumhuriyet 75 & 12.1 & 19 & 23.sawyt-327 & 12.0 \\
\hline 5 & Ziyabey 98 & 10.2 & 20 & 23.sawyt-332 & 13.1 \\
\hline 6 & Nusrat & 12.6 & 21 & 23.sawyt-339 & 12.1 \\
\hline 7 & Ceyhan 99 & 11.1 & 22 & 23.sawyt-344 & 12.7 \\
\hline 8 & Özel sektör çeşidi & 9.1 & 23 & 23.sawyt-347 & 12.4 \\
\hline 9 & Siyez & 12.4 & 24 & 36.eswyt-106 & 12.0 \\
\hline 10 & Gıcık buğday & 14.6 & 25 & 36.eswyt-115 & 12.6 \\
\hline 11 & Evren & 11.8 & 26 & 36.eswyt-122 & 10.6 \\
\hline 12 & Çalıbasan & 13.3 & 27 & 36.eswyt-123 & 10.9 \\
\hline 13 & Akbuğday & 9.7 & 28 & 36.eswyt-136 & 12.6 \\
\hline 14 & 23.sawyt-306 & 12.6 & 29 & 36.eswyt-144 & 12.0 \\
\hline 15 & 23.sawyt-308 & 12.1 & 30 & 36.eswyt-145 & 12.2 \\
\hline
\end{tabular}

Genel ortalama

Tescilli çeşitlerin ortalaması

Yerel çeşitlerin ortalaması

Hatların ortalaması

12.2

Minimum (Min.)

9.1

Maksimum (Maks.)

14.6

$\mathrm{S}^{2}$ (varyans)

S (St. sapma)

$\mathrm{S}_{\mathrm{x}}$ (Ort. St. Hatası)

CV (\%)

ark, 2013), 53.5-30.4 ml (Aktaş ve Eren, 2014), 19-31 ml (Erekul ve ark., 2016), 28.25-55 ml (Aktaş ve ark., 2017) arasında bulmuştur.

$30 \mathrm{ml}$ ve üzeri sedimantasyon değeri gösteren unlar ekmek yapımı için çok iyi değere sahip kaliteli olarak değerlendirilir. 15-20 $\mathrm{ml}$ arası sedimantasyon değeri olan unlar zayıf, 20-25 ml orta olarak değerlendirilirken 25-30 ml arası sedimantasyon değeri ise ekmek yapımına uygun iyi kalite olarak değerlendirilmektedir (Ünal, 2003). Ünal (2003)'ın yaptığı çalışmaya göre değerlendirdiğimiz genotiplerden çeşit ve hatlar çok iyi kalite, yerel çeşitler ise
Zeleny Sedimantasyon yönünden zayıf kategoriye girmektedir.

\section{Farinograf Testi}

Hamurun yoğurulma özellikleri hakkında bilgi veren bir cihaz olan farinograf, unun ekmek kalitesi için önemli bir testtir. Bu cihaz ile hamurun su absorbsiyonu, gelişme süresi, hamurun stabilitesi ve yumuşama derecesi ile ilgili bilgiler verir.

\section{Farinograf gelişme (yoğurma) süresi (FGS)(dk)}

Hamurun yoğrulmaya başlaması ile tepe noktasına gelinceye kadar geçen süre (dakika) olarak tanımlanır. 
Çizelge 3. Genotiplerin zeleny sedimantasyon değerleri (ml)

\begin{tabular}{|c|c|c|c|c|c|}
\hline No & Genotip & Zeleny $\operatorname{sedim}(\mathrm{ml})$ & No & Genotip & Zeleny $\operatorname{sedim}(\mathrm{ml})$ \\
\hline 1 & Meltem & 34 & 16 & 23.sawyt-314 & 38 \\
\hline 2 & Efe & 39 & 17 & 23.sawyt-316 & 39 \\
\hline 3 & Kayra & 45 & 18 & 23.sawyt-321 & 33 \\
\hline 4 & Cumhuriyet 75 & 26 & 19 & 23.sawyt-327 & 32 \\
\hline 5 & Ziyabey 98 & 28 & 20 & 23.sawyt-332 & 34 \\
\hline 6 & Nusrat & 38 & 21 & 23.sawyt-339 & 41 \\
\hline 7 & Ceyhan 99 & 45 & 22 & 23.sawyt-344 & 50 \\
\hline 8 & Özel sektör çeşidi & 24 & 23 & 23.sawyt-347 & 46 \\
\hline 9 & Siyez & 14 & 24 & 36.eswyt-106 & 39 \\
\hline 10 & Gıcık buğday & 25 & 25 & 36.eswyt-115 & 40 \\
\hline 11 & Evren & 20 & 26 & 36.eswyt-122 & 32 \\
\hline 12 & Çalıbasan & 24 & 27 & 36.eswyt-123 & 31 \\
\hline 13 & Akbuğday & 15 & 28 & 36.eswyt-136 & 43 \\
\hline 14 & 23.sawyt-306 & 37 & 29 & 36.eswyt-144 & 44 \\
\hline 15 & 23.sawyt-308 & 41 & 30 & 36.eswyt-145 & 43 \\
\hline \multicolumn{2}{|c|}{ Genel ortalama } & 35 & & & \\
\hline \multicolumn{2}{|c|}{ Tescilli çeşitlerin ortalaması } & 34,9 & & & \\
\hline \multicolumn{2}{|c|}{ Yerel çeşitlerin ortalaması } & 19.6 & & & \\
\hline \multicolumn{2}{|c|}{ Hatların ortalaması } & 39.0 & & & \\
\hline \multicolumn{2}{|c|}{ Minimum (Min.) } & 14 & & & \\
\hline \multicolumn{2}{|c|}{ Maksimum (Maks.) } & 50 & & & \\
\hline \multicolumn{2}{|c|}{$\mathrm{S}^{2}$ (varyans) } & 86.09 & & & \\
\hline \multicolumn{2}{|c|}{ S (St. sapma) } & 9.28 & & & \\
\hline \multicolumn{2}{|c|}{$\mathrm{S}_{\mathrm{x}}$ (Ort. St. Hatası) } & 1.69 & & & \\
\hline \multicolumn{2}{|c|}{ CV (\%) } & 26.77 & & & \\
\hline
\end{tabular}

Çalışmanın farinograf gelişme süresi ortalaması $9.71 \mathrm{dk}$ olan genotiplerin en yüksek değeri $19.19 \mathrm{dk}$ ile 22 nolu hat en düşük değeri ise $1.15 \mathrm{dk}$ ile Çalıbasan almıştır. Yerel çeşitlerin Farinograf gelişme süresi ortalamaları $1.84 \mathrm{dk}$ ile çalışmanın ortalamasını düşürmektedir (Çizelge 4.).

Zayıf unların gelişme süreleri kısa kuvvetli unların daha uzundur (Pyler, 1988). Yapılan bir çalışmada Triticum aestivum L. buğdayında 4.0 dakika olan gelişme süresi, Triticum monococcum L. (Einkorn) buğdayında ise 0.5 dakika olarak belirtilmiştir (D'egidio ve ark, 1991).

Çizelge 4.'e göre hatların FGS değerleri çeşit ve yerel çeşitlere göre daha yüksek tespit edilmiştir. Buda hatlardan elde edilen unların kuvvetli olduğu sonucunu göstermektedir.

\section{Farinograf su absorbsiyon kapasitesi (FSAB) (\%)}

Belirli bir yoğunlukta hamur oluşumu için ilave edilen su miktarı o unun su absorbsiyon kapasitesini gösterir. Su absorbsiyon kapasitesinin yüksek olması ekmek yapımı için aranan bir özelliktir (Uluöz, 1965).

Genotiplerin farinograf su absorbsiyon kapasitelerine bakıldığında \%66.6 değeri ile Efe çeşidi en yüksek, 20 nolu hat ise \%57.6 ile en düşük değeri vermiştir. Çalışmanın FSAK' lerinin ortalaması \%61.6 olarak saptanmıştır (Çizelge 4.).

Unların su absorbsiyon kapasiteleri ile protein miktarları arasında bir bağlantı vardır. Genelde protein ve gluten miktarları yüksek olan unların su absorbsiyon kapasiteleri de yüksek olduğu kabul edilmektedir (Ünal, 1979; Bloksma, 1990; Özer, 2000).

Benzer çalışmalarda farinograf su absorbsiyon kapasitelerinin \%52.6-65.90 (Aydoğan ve ark., 2013), \%48.4-63 (Emeksizoğlu, 2016), \%48.5-74.0 (Evlice ve ark., 2016) arasında değişim gösterdiğini bulmuşlardır.

Çalışmanın sonuçları diğer çalışmalarla paralellik göstermektedir.

\section{Farinografstabilite (FS) (dk)}

Hamur oluşumu esnasında paletlere karşı gösterdiği direncin bir süreliğine değişmeden sabit kalma süresi o hamurun stabilitesini gösterir.

Çalışmanın farinograf stabilite değerlerin çeşit ortalamaları $12.1 \mathrm{dk}$, hat ortalamaları $17.5 \mathrm{dk}$ ve yerel çeşitlerin ortalamaları ise $2.2 \mathrm{dk}$ olarak tespit edilmiştir (Çizelge 4.). 
Çizelge 4.Genotiplerin farinograf değerleri

\begin{tabular}{|c|c|c|c|c|c|c|c|}
\hline No & Genotip & Fgs (dk) & Fsab (\%) & Fs (dk) & Fyum10 (bu) & Fyum12 (bu) & Fqn (mm) \\
\hline 1 & Meltem & 3.53 & 64.3 & 5.3 & 66 & 149 & 76 \\
\hline 2 & Efe & 6.58 & 66.6 & 12.4 & 17 & 49 & 146 \\
\hline 3 & Kayra & 17.25 & 65.6 & 18.0 & 21 & 41 & $>200$ \\
\hline 4 & Cumhuriyet 75 & 7.17 & 58.8 & 18.0 & 8 & 18 & $>200$ \\
\hline 5 & Ziyabey 98 & 6.38 & 59.9 & 8.4 & 18 & 59 & 122 \\
\hline 6 & Nusrat & 9.26 & 60.9 & 15.1 & 4 & 35 & 200 \\
\hline 7 & Ceyhan 99 & 19.02 & 61.0 & 18.0 & 65 & 88 & $>200$ \\
\hline 8 & Özel sektör çeşidi & 2.05 & 59.7 & 1.6 & 220 & 262 & 30 \\
\hline 9 & Siyez & 1.43 & 59.2 & 1.2 & 269 & 304 & 22 \\
\hline 10 & Gıcık buğday & 2.35 & 63.6 & 1.6 & 213 & 263 & 35 \\
\hline 11 & Evren & 2.24 & 63.0 & 3.3 & 150 & 207 & 47 \\
\hline 12 & Çalıbasan & 1.15 & 59.9 & 2.0 & 64 & 72 & 24 \\
\hline 13 & Akbuğday & 2.03 & 58.0 & 3.1 & 88 & 119 & 49 \\
\hline 14 & 23.sawyt-306 & 9.55 & 62.5 & 18.0 & 1 & 26 & $>200$ \\
\hline 15 & 23.sawyt-308 & 10.32 & 62.8 & 18.0 & 4 & 33 & $>200$ \\
\hline 16 & 23.sawyt-314 & 18.57 & 63.3 & 18.0 & 50 & 75 & $>200$ \\
\hline 17 & 23.sawyt-316 & 7.45 & 61.8 & 18.0 & 8 & 29 & $>200$ \\
\hline 18 & 23.sawyt-321 & 16.43 & 58.0 & 18.0 & 36 & 65 & $>200$ \\
\hline 19 & 23.sawyt-327 & 18.24 & 58.5 & 18.0 & 51 & 81 & $>200$ \\
\hline 20 & 23.sawyt-332 & 6.30 & 57.6 & 15.3 & 4 & 25 & 199 \\
\hline 21 & 23.sawyt-339 & 18.12 & 62.6 & 18.0 & 63 & 81 & $>200$ \\
\hline 22 & 23.sawyt-344 & 19.19 & 63.5 & 18.0 & 36 & 64 & $>200$ \\
\hline 23 & 23.sawyt-347 & 9.03 & 61.2 & 16.5 & 2 & 31 & 154 \\
\hline 24 & 36.eswyt-106 & 11.10 & 62.3 & 18.0 & 4 & 46 & $>200$ \\
\hline 25 & 36.eswyt-115 & 9.26 & 62.0 & 18.0 & 6 & 33 & $>200$ \\
\hline 26 & 36.eswyt-122 & 18.04 & 60.2 & 18.0 & 28 & 56 & $>200$ \\
\hline 27 & 36.eswyt-123 & 9.27 & 58.4 & 18.0 & 3 & 33 & $>200$ \\
\hline 28 & 36.eswyt-136 & 7.17 & 66.1 & 13.5 & 28 & 45 & 104 \\
\hline 29 & 36.eswyt-144 & 9.01 & 65.0 & 18.0 & 7 & 34 & $>200$ \\
\hline 30 & 36.eswyt-145 & 14.07 & 63.1 & 18.0 & 44 & 59 & $>200$ \\
\hline \multicolumn{2}{|c|}{ Genel ortalama } & 9.72 & 61.6 & 13.5 & 52.6 & 82.7 & 93 \\
\hline \multicolumn{2}{|c|}{ Tescilli çeşitlerin ortalaması } & 8.91 & 62.1 & 12.1 & 52.4 & 87.6 & 114.8 \\
\hline \multicolumn{2}{|c|}{ Yerel çeşitlerin ortalaması } & 1.84 & 60.7 & 2.2 & 156.8 & 193.0 & 35.4 \\
\hline \multicolumn{2}{|c|}{ Hatların ortalaması } & 12.42 & 61.7 & 17.5 & 22.1 & 48.0 & 152.3 \\
\hline \multicolumn{2}{|c|}{ Minimum (Min.) } & 1.15 & 57.6 & 1.2 & 1 & 18 & 22 \\
\hline \multicolumn{2}{|c|}{ Maksimum (Maks.) } & 19.10 & 66.6 & 18.0 & 269 & 304 & $>200$ \\
\hline \multicolumn{2}{|c|}{$\mathrm{s}^{2}$ (varyans) } & 36.24 & 6.43 & 42.50 & 4915.83 & 5913.37 & - \\
\hline \multicolumn{2}{|c|}{ S (St. sapma) } & 6.02 & 2.54 & 6.52 & 70.11 & 76.90 & - \\
\hline \multicolumn{2}{|c|}{$\mathrm{S}_{\mathrm{x}}$ (Ort. St. Hatası) } & 1.10 & 0.46 & 1.19 & 12.80 & 14.04 & - \\
\hline \multicolumn{2}{|c|}{ CV (\%) } & 61.94 & 4.11 & 48.25 & 133.29 & 92.95 & - \\
\hline
\end{tabular}


2010-11 yıllarında 6 lokasyonda 9 denemeye ait 199 adet ekmeklik buğday hat ve çeşitlerinde yapılan çalışmada genotiplerde stabilite değeri 1.0-20.0 dakika arasında değişim göstermiş, ortalama olarak hatlarda $9.2 \mathrm{dk}$, çeşitlerde ise $9.0 \mathrm{dk}$ olarak tespit edilmiştir (Evlice ve ark., 2016).

Yoğurma toleransı stabilite süresi uzun olan hamurlarda yüksek, stabilite süresi kısa olan hamurlarda ise düşüktür. Stabilite süreleri kısa olan hamurların mekanik işlemlere ve fermantasyona karşı dayanıklıkları daha azdır (Pyler, 1988; Walker ve Hazelton, 1996).

Nitekim çalışmadaki yerel çeşitlerin verdikleri düşük stabilite değerleri ile fermantasyon ve mekanik işlemlere karşı dirençlerinin az olduğu söylenebilir.

Farinograf 10. dakika yumuşama değeri (FYUM10) (BU)

Farinograf 10. dakika yumuşama değeri, kurvenin tepe noktasından 10 dakika sonra kurve ortasının 500 konsistens çizgisine olan uzaklığıdır. Bu değerin düşük olması istenir (Aydoğan ve ark., 2012).

Çalışmada $1 \mathrm{BU}$ değeri ile ekmeklik yapımına uygun en iyi genotip 14 numaralı hat olarak göze çarpmakta, 269 BU değeri ile Siyez yüksek değerde karşımıza çıkmaktadır. 52.4 BU ortalama değeri ile çeşitlerin 10 . dakika yumuşama değerlerini inceleyecek olursak en yüksek değeri özel sektör çeşidi (220 BU) en düşük değeri ise Nusrat çeşidi vermiştir. Yerel çeşitlerin en yüksek Farinograf 10. dakika yumuşama değeri Siyez'de (269 BU) görülürken, Çalıbasan (64) en düşük değeri vermiştir. Hatlar ise 1-63 BU arasında değişim göstermiştir (Çizelge 4.).

Önemli bir kalite kriteri olan yumuşama derecesinin düşük olması istenir. Yüksek değere sahip hamurların işlemeye uygun olmadığı, fermantasyon toleransının düşük olduğu anlamına gelmektedir (Elgün ve ark.,2005). Yerel çeşitlerle hat ve çeşitler karşılaştırıldığında, yerel çeşitlerin fermantasyon toleransının düşük olduğu ve hamur işlemeye uygun olmadığı görülmektedir.

Farinograf 12. dakika yumuşama değeri (FYUM12) (BU)

Kurvenin tepe noktasından 12 dakika sonra, kurve ortasının 500 konsistens çizgisine olan uzaklığına yumuşama derecesi denir ve konsistens derecesi cinsinden ifade edilir

Çalışma 25-304 BU arasında farinograf 12. dakika yumuşama değeri vermiştir. 20 numaralı hat en düşük, Siyez ise en yüksek değerde görülmektedir. Çalışmadaki farinograf 12. dakika yumuşama değeri ortalaması ise 82.7 BU olarak tespit edilmiştir (Çizelge 4.).

Benzer bir çalışmada, 12. dakika yumuşama değeri en yüksek 231 FU ile 16 nolu hat, en düşük değer ise 2.5 FU ile 5 nolu hat bulunmuştur (Aydogan ve ark., 2012).

\section{Farinograf kalite numarası (FQN)(mm)}

Kurvenin başlangıcından itibaren oluşan yeni 500 konsistens çizgisinden $30 \mathrm{FU}$ aşağı düştüğü süre her dakika $10 \mathrm{~mm}$ olmak şartı ile hesaplanarak tanımlanır. Gözlenen sayının yüksek olması istenir. Çalışmada farinograf kalite numarası ortalamaları çeşitlerde $114.8 \mathrm{~mm}$, hatlarda $152.3 \mathrm{~mm}$ ve yerel çeşitlerde ise 35.4 mm'dir (Çizelge 4.).

Şahin ve ark. (2017)'nın yürütmüş oldukları bir çalışmada, çeşitlerin farinograf kalite sayısı (FQN) ortalama 124.9 olarak belirlenmiştir. En yüksek FQN değerine Bozkır (172.7), Eraybey (166..0) ve Tosunbey (165.0) çeşitleri, en düşük değere ise Gerek-79 çeşidi (51.0) sahip olmuştur.

Çalışma içerisinde farinograf kalite numarası değerlerine göre ekmek yapımına en uygun grup denemedeki hatlar olarak görülmektedir.

\section{SONUÇ}

Araştırma sonuçlarına göre bazı ekmeklik buğday çeşit, hat ve yerel çeşitlerin kalite özellikleri bakımından farklılıklar ortaya çıkmıştır.

Genotiplerin ortalama protein değerleri \%12.1 olarak bulunmuşken en yüksek protein değerini \%14.6 ile yerel çeşit olan Gıcık buğday vermiştir. En düşük protein değerine sahip olan ise \%9.1 ile özel sektör çeşidi olmuştur (Çizelge 5.).

Çizelge 5. Genotiplerin kalite değerleri ortalaması

\begin{tabular}{llll}
\hline & $\begin{array}{l}\text { Tescilli } \\
\text { çeşitlerin } \\
\text { ortalaması }\end{array}$ & $\begin{array}{l}\text { Yerel } \\
\text { çeşitlerin } \\
\text { ortalaması }\end{array}$ & $\begin{array}{l}\text { Hatların } \\
\text { ortalaması }\end{array}$ \\
\hline $\begin{array}{l}\text { Protein oranı (\%) } \\
\text { Zeleny }\end{array}$ & 11.7 & 12.4 & 12.2 \\
sedimantasyon (ml) & 34.9 & 19.6 & 39.0 \\
Fgs (dk) & 8.91 & 1.84 & 12.42 \\
Fsab (\%) & 62.1 & 60.7 & 61.7 \\
Fs (dk) & 12.1 & 2.2 & 17.5 \\
Fyum 10 (bu) & 52.4 & 156.8 & 22.1 \\
Fyum 12 (bu) & 87.6 & 193.0 & 48.0 \\
Fqn (mm) & 114.8 & 35.4 & 152.3 \\
\hline
\end{tabular}

Çalışmada en düşük Zeleny sedmimantasyon değerlerini sırasıyla Siyez, Ak buğday, Evren, özel sektör çeşidi, Çalıbasan ve Gıcık buğday vermiştir. En yüksek değeri ise 50 $\mathrm{ml}$ ile 22 nolu hat vermiştir.

Farinograf özellikleri bakımından genotipler toplu olarak değerlendirildiğinde, hatlardan elde edilen unların hamur özelliklerinin daha iyi olduğu ve bunları çeşitlerin izlediği söylenebilir. Yerel çeşitlerin hamur özellikleri düşük kalmıştır (Çizelge 5.).

Son zamanlarda popüler olan yerel çeşitler ele alındığında bunların protein oranları yüksek çeşitler olduğu gözlemlenmiştir. Ancak Zeleny sedimantasyon değerleri bakımından zayıf özellik göstermiştir. Buda protein kalitelerinin düşük olduğunun bir göstergesidir. Nitekim zayıf hamur oluşturmuşlardır. Bu durumda yerel çeşitlerin somun ekmek yapımından ziyade yassı ekmek yapımına uygun oldukları söylenebilir. Bu yerel çeşitlerin incelenen özelliklerinin yanında beslenme fizyolojisi bakımından da incelenmesi gerekmektedir. Çalışma, farklı lokasyonlarda yetiştirilen genotipleri içeren 1 yıllık sonuçları vermektedir. 
Tüm genotiplerin aynı denemede ve farklı lokasyonlarda denenmesi yararlı olacaktır.

\section{TEŞEKKÜR}

Adnan Menderes Üniversitesi Bilimsel Araştırma Projeleri Birimine ZRF-19002 no'lu proje kapsamında yaptıkları desteklerden dolayı teşekkür ederiz. Analizler Konya Bahri Dağdaş Uluslararası Tarımsal Araştırma Enstitüsü Müdürlüğü kalite ve teknoloji laboratuvarında yapılmıştır. Emeği geçenlere teşekkür ederiz.

\section{KAYNAKLAR}

Akçura M (2001) Ethepton ve Mepiquat Chloride Uygulamasının Kahramanmaraş Koşullarındaki Ekmeklik Buğday (Triticum aestivum L.) Genotiplerinin Verim ve Verim

Unsurları Üzerine Etkisi. Yüksek Lisans Tezi, Kahramanmaraş Sütçü İmam Üniversitesi, Kahramanmaraş.

Aktaş B, Eren H (2014) Bazı Ekmeklik Buğday (Triticum aestivum L.) Çeşitlerinin Tane Verimi Stabilitesi ve Kalite Özelliklerinin Belirlenmesi. Tarla Bitkileri Merkez Araştırma Enstitüsü Dergisi, 23(2) : 69-76.

Aktaş H, Karaman M, Oral E, Kendal E, Tekdal S (2017) Bazı Ekmeklik Buğday Genotiplerinin (Triticum aestivum L.) Doğal Yağış Koşullarındaki Verim ve Kalite Parametrelerinin Değerlendirilmesi. Tarla Bitkileri Merkez Araştırma Enstitüsü Dergisi, 26(1) : 86-95.

Anonymous (1990) AACC (26-95). Approved methods of the american association of cereal chemist. USA.

Anonymous (2008) International Association for Cereal Science and Technology (ICC), Vienna, Standart No: $116 / 1$.

Anonymous (2009) Approved methodologies. www.leco.com/resources/approved methods

Anonim (2020) Milli Çeşit Listesi, https://www.tarimorman.gov.tr/BUGEM/TTSM/

Sayfalar/Detay.aspx?Sayfald=85. Erişim tarihi: 23/04/2020

Aydoğan S, Göçmen Akçacık A, Şahin M, Kaya Y, Koç $H$, Görgülü MN, Ekici M (2012) Ekmeklik Buğday Unlarında Alveograf, Farinograf ve Miksografta Ölçülen Reolojik Özellikler Arasındaki Ilişkinin Belirlenmesi. Süleyman Demirel Üniversitesi Ziraat Fakültesi Dergisi, 7(1) : 74-82.

Aydoğan S, Göçmen Akçacık A, Şahin M, Önmez H, Demir B, Yakışır E (2013) Ekmeklik Buğday Çeşitlerinde Fizikokimyasal ve Reolojik Özelliklerin Belirlenmesi. Tarla Bitkileri Merkez Araştırma Enstitüsü Dergisi, 22(2) : 74-85.

Bloksma AH (1990) Dough Structure, Dough Rheology and Baking Quality. Cereal Foods World, 35(2) : 237-242.

Borghi B, Castagna R, Corbellini M, Heun M, Salamini F (1996) Bread Making Quality of Einkorn Wheat. Cereal Chemistry, 73(2) : 208-214.

Braun HJ, Zincirci N, Altay F, Atlı A, Avcl M, Eser V, Kambertay M, Payne TS (2001) Turkish wheat pool. pp. 851-879. In: Bonjean, A. P., and W. J. Agnus (Eds.) The World Wheat Book: A History of Wheat Breeding, Lavosier, Paris.
Bulut S (2012) Ekmeklik Buğdayda Kalite. Erciyes Üniversitesi Fen Bilimleri Enstitüsü Dergisi, 28(5) : 441-446.

Corbellini M, Empilli P, Vaccino P, Brandolini B, Heun M, Salamini F (1999) Einkorn Characterization for Bread and Cookie Production in Relationto Protein Subunit Composition. Cereal Chemistry, 76(5) : 727-733.

D'Egidio MG, Nardi S, Vallega V (1991) Quality of diploid wheat, Triticum monococcum L. P. 205-208 in Proc. Cereals Intern. Conf.,Brisbane (D.J. Martin and C.W. Wrigley, eds.). Royal Australian Chemical Institute, Parkville, Australia.

Elgün A, Türker S, Bilgiçli N (2001) Tahıl ve Ürünlerinde Analitik Kalite Kontrolü. Selçuk Üniversitesi Ziraat Fakültesi Gıda Mühendisliği Bölümü Yayınları. No.2. Konya.

Elgün A, Türker S, Bilgiçli N (2005) Tahıl ve Ürünlerinde Analitik Kalite Kontrolü. Selçuk Üniversitesi Ziraat Fakültesi Gıda Mühendisliği Bölümü Ders Notları, Konya, 112.

Emeksizoğlu B (2016) Kastamonu Yöresinde Yetiştirilen Siyez (Triticum monococcum L.) Buğdayının Bazı Kalite Özellikleri ile Bazlama ve Erişte Yapımında Kullanımının Araştırması. Doktora Tezi, Ondokuz Mayıs Üniversitesi Fen Bilimleri Enstitüsü, Samsun.

Erekul O, Oncan F, Erkul A, Engün B, Koca YO (2005) İleri Ekmeklik Buğday Hatlarında Verim ve Bazı Kalite Özelliklerinin Sonuçlanması. Türkiye VI. Tarla Bitkileri Kongresi, 5-9 Eylül 2005, Antalya, 111-116.

Erekul O, Yiğit A, Koca YO, Ellöer F, Weib K (2016) Bazı Ekmeklik Buğday (Triticum aestivum L.) Çeşitlerinin Kalite Potansiyelleri ve Beslenme Fizyolojisi Açısından Önemi. Tarla Bitkileri Merkez Araştırma Enstitüsü Dergisi, Özel sayı-1 : 31-36

Evlice A, Pehlivan A, Külen S, Keçeli A, Şanal T, Karaca K, Salantur A (2016) Ekmeklik Buğday (Triticum aestivum L.) Genotiplerinde Ekmek Hacmi ve Bazı Kalite Parametreleri Arasındaki İlişkilerin İncelenmesi. Tarla Bitkileri Merkez Araştırma Enstitüsü Dergisi, 25 (Özel sayı-1) : 12-18.

Kan $M$, Küçükçongar $M$, Keser $M$, Morgounov $A$, Muminjanow H, Özdemir F, Qualset C (2015) WheatLand races in Farmers' Fields in Turkey: National Survey, Collection, and Conservation, 20092014. FAO, Ankara, http://www.fao.org/3/ai5316e.pdf. (Erişim tarihi: 23/04/2020).

Kihlberg I, Johansson L, Kohler A, Risvik EC (2004) Sensory Qualities of Whole WheatPanbread: Influence of Farmingsystem, Year of Harvest and Baking Technique. J.CerealSci., $39: 67-84$

Kün E (1996) Tahıllar-ı (Serin İklim Tahılları). Ankara Üniversitesi Ziraat Fakültesi Yayınları, Ankara, 1451.

Mader P, Hahn D, Dubois D, Gunst L, Alfoldi T, Bergmann H, Oehme M, Amado R, Schneider H, Graf U, Velimirov A, Fliebbach A, Niggli $U$ (2007) Wheat quality in organic and conventional farming: results of a 21 year field experiment. J. Sci. FoodAgric., 87: 1826-1835. 
Menderis M (2006) Güneydoğu Anadolu Bölgesi Koşullarında Geliştirilen Bazı Ekmeklik Buğday (Triticum aestivum L.) Hatları Ile Yetiştirilen Bazı Buğday Çeşitlerinin Kalite Özelliklerinin Belirlenmesi. Yüksek Lisans Tezi, Harran Üniversitesi, Şanlıurfa.

Morgounov A, Keser M, Kan M, Küçükçongar M, Özdemir F, Gummanow N, Muminjanov H, Zuev E, Qualset C (2016) Wheat Landraces Currently Grown in Turkey: Distribution, Diversity and Use. CropScience, 56 : 113.

Mpofu A, Sapirstein HD, Beta T (2006) Genotyp eand Environmental Variation in Phenolic Content, Phenolic Acid Composition, and Antioxidant Activity of Hard Spring Wheat. J. Agric. FoodChem. 54, 1265-1270.

Özer Ç (2000) Bazı Islah Çeşidi Ekmeklik Buğdayların ve Piyasada Satılan Tip-1 Unların Kalitelerinin Belirlenmesinde Kullanılan Farklı Metotların Kıyaslanması. Doktora Tezi, Ege Üniversitesi Fen Bilimleri Enstitüsü, İzmir.

Pyler EJ (1988) Baking Science and Technology. Sosland Publishing Co. USA, 1345s.

Serpen A, Göçmen Akçacık A, Karagoz A, Koksel H 2008 Phytochemical quantification and total antioxidant capacities of emer (Triticumdicoccon Schrank) and Einkorn (Triticum monococcum L.) wheatl and races. J.Agric.FoodChem.,Vol. 56, 7285-7292.

Şahin M, Göçmen Akçacık A, Aydoğan S, Hamzaoğlu S, Demir B, Yakışır E (2017) Kışlık Ekmeklik Buğday Çeşitlerinde Zeleny Sedimantasyon ile Verim ve Bazı Kalite Özellikleri Arasındaki İlişkilerin İncelenmesi. Journal of Bahri Dagdas Crop Research, 6 (1): 10-21.

Tayyar \$̧ (2005) Biga Koşullarında Yetiştirilen Farklı Ekmeklik Buğday (Triticum aestivum L.) Çeşit ve Hatların Verim
SEVIM i, EREKUL O

ve Bazı Kalite Özelliklerinin Saptanması. Akdeniz Üniversitesi Ziraat Fakültesi Dergisi, 18(3) : 405-409.

Uluöz M (1965) Buğday Unu Ve Ekmeklik Analiz Metotları. Ege Üniversitesi Ziraat Fakültesi Yayınları, 57: 101.

Ünal SS (1979) Buğdaylarda Kaliteyi Etkileyen Faktörler ve Birbirleri Arasındaki İlişkiler. Ege Üniversitesi Gıda Fakültesi Dergisi, 4(2) : 71-79.

Ünal S, Boyacıoğlu MH (1984) Hamurun Reolojik Özellikleri. Gıda. 9(1) : 13- 20

Ünal S (2003) Buğday Un ve Kalitesinin Belirlenmesinde Uygulanan Yöntemler, Nevşehir Ekonomisinin Sorunları ve Çözüm Önerileri: Un Sanayi Örneği. Nevşehir Ekonomisi Sempozyumu Bildirileri I, 27-28 Haziran 2003, Nevşehir, 15-29.

Walker CE, Hazelton JI (1996) DoughRheologicalTests. CerealFoodsWorld, 41(1): 23-28.

Williams P, Haramein FJ, Nakkoul H, Rihavi S (1986a) Evaluation Methods of 7th International WinterWheatPerformance Nursery Grown in 1975. Research Bulleten. USA

Williams P, Haremein FJ, Nakkaul H, Rihawi S (1986b) CropQuality Evaluation Methods and Quidelines. Technical Mansal, Syria, 14.

Yiğit A (2019) Farklı Ekolojik Koşulların Buğday Genotiplerinde Verim, Ekmeklik Buğday Kalitesi ve Antioksidan Özellikleri Üzerine Etkilerinin Belirlenmesi. Doktora Tezi, Aydın Adnan Menderes Üniversitesi Fen Bilimleri Enstitüsü, Aydın.

Yurtsever N (1984) Deneysel İstatistik Metotları. Tarım Orman ve Köyişleri Bakanlığı, Köy Hizmetleri Genel Müdürlüğü, Genel Yayın No: 121, Teknik Yayın No: 56, Ankara. 
